\title{
EFFECTS OF MARCAINE, A MYOTOXIC DRUG, ON MACROMOLECULAR SYNTHESIS IN MUSCLE
}

\author{
Marcia E. Johnson and George H. Jones \\ Department of Cellular and Molecular Biology, Division of Biological Sciences, \\ The University of Michigan Ann Arbor, MI 48109, U.S.A.
}

(Received 28 June 1977; accepted 21 October 1977)

\begin{abstract}
The effects of Marcaine (bupivacaine) on RNA and protein synthesis in skeletal muscle have been studied. The drug did not affect RNA synthesis by pieces of rat tibialis anterior at concentrations as high as $0.5 \%(\mathrm{w} / \mathrm{v})$, nor did it affect cell-free transcription of calf thymus DNA by wheat germ RNA polymerase II. In contrast, Marcaine inhibited protein synthesis by muscle chunks, and also inhibited ["H]leucine incorporation by cell-free components prepared from muscle. Specifically, the drug significantly inhibited aminoacylation of muscle transfer RNA with the amino acids leucine, methionine, lysine and valine ( $50-90$ per cent) at a concentration of $0.5 \%$ and also inhibited elongation of polypeptide chains at the same concentration. Marcaine $(0.5 \%)$ also inhibited aminoacylation of tRNA in cell-free systems derived from rat liver and from murine myeloma RPC-20, but it did not inhibit as strongly as in skeletal muscle. Interestingly, $0.5 \%$ Marcaine had no effect on the acylation of tRNA with leucine, methionine, lysine or valine when cell-free components from Escherichia coli were used.
\end{abstract}

Marcaine (bupivacaine, $d l$-1-butylpipecoloxylidide) was introduced clinically as a local anesthetic in 1963 [1]. Since that time, it has been shown to be a myotoxic agent, producing rapid degeneration of skeletal muscle fibers [2]. Most recently, this degenerative effect has been used to aid in skeletal muscle transplantation studies. Treatment of certain mammalian skeletal muscles with Marcaine, after removal of the muscle from the animal but prior to autogenous free grafting, results in a rapid degeneration of the transplanted muscle followed by a regenerative phase in which the weight and contractile properties of the transplants are restored to levels which are 50-90 per cent those of control muscles [3, 4]. Max and Rifenberick [4] have also shown that the activities of several muscle enzymes decrease during the degenerative phase after Marcaine treatment but increase during the subsequent regeneration after transplantation. These last results represent almost all the available data on the biochemical effects of Marcaine and essentially nothing is known of the direct effects of the drug at the biochemical level. It seemed advisable, therefore, to examine certain molecular aspects of Marcaine action in conjunction with its use in muscle transplantation studies. The experiments reported below were designed to examine the effects of Marcaine on protein and RNA synthesis in muscle. The effects of the drug on the incorporation of precursors into RNA and protein by muscle cells and by cell-free transcription and translation systems are described.

\section{MATERIALS AND METHODS}

Materials. Marcaine-HCl was generously supplied by Dr. F. C. Nachod (Sterling-Winthrop Research Institute, Rensselaer, New York) and was prepared as 5 or $10 \%(\mathrm{w} / \mathrm{v})$ solutions in $50 \%$ ethanol. Laboratory rats weighing $200-250 \mathrm{~g}$ were used as a source of skeletal muscle. Minimal essential Eagle's medium minus leucine (MEM) was from Gibco, Grand Island, New York. $\left[{ }^{3} \mathrm{H}\right] l$ eucine (58 Ci/m-mole), $\left[{ }^{35} \mathrm{~S}\right]$ methionine $(550 \mathrm{Ci} / \mathrm{m}$-mole $)$, $\left[{ }^{3} \mathrm{H}\right]$ methionine $(6 \mathrm{mCi} / \mathrm{m}-\mathrm{mole}),\left[{ }^{3} \mathrm{H}\right]$ uridine $(49$ $\mathrm{Ci} / \mathrm{m}$-mole) and $\left[{ }^{3} \mathrm{H}\right] \mathrm{UTP}(45 \mathrm{Ci} / \mathrm{m}$-mole) were from Amersham/Searle while $\left[{ }^{3} \mathrm{H}\right]$ lysine $(38.9 \mathrm{Ci} / \mathrm{m}$-mole) and $\left[{ }^{3} \mathrm{H}\right]$ valine $(1.3 \mathrm{Ci} / \mathrm{m}$-mole $)$ were from New England Nuclear. Calf thymus DNA was from Sigma and Escherichia coli tRNA from Schwarz/ Mann. All other chemicals were reagent grade.

Incubation of muscle chunks with $\left[{ }^{3} \mathrm{H}\right]$ uridine and $\left[{ }^{3} \mathrm{H}\right]$ leucine. Tibialis anterior was the muscle routinely used in all the studies reported below. The muscles were removed from one or both hind limbs of a freshly killed rat, rinsed briefly in MEM and cut into chunks of about $1 \mathrm{~mm}^{3}$. Reaction mixtures for RNA or protein synthesis contained, per $\mathrm{ml}$; MEM, $0.50 \mathrm{ml}$; a mixture of nonradioactive amino acids (alanine, asparagine, aspartic acid, glutamic acid, proline, serine and glycine), $0.10 \mu$ mole each; $\left[{ }^{3} \mathrm{H}\right]$ uridine (for RNA synthesis)or $\left[{ }^{3} \mathrm{H}\right]$ leucine (for protein synthesis), $10 \mu \mathrm{Ci}$; Marcaine, 0.01 to $0.50 \%$ $(w / v)$ final concentration, distilled water to $1 \mathrm{ml}$ and two $1 \mathrm{~mm}^{3}$ muscle chunks. The $\mathrm{pH}$ of each reaction mixture was adjusted to about 7.2 before adding the muscle. Reaction mixtures were incubated for 90 min at $37^{\circ}$ with shaking; the reactions were stopped by adding $10 \%$ trichloroacetic acid to the reaction vessels. Protein synthesis mixtures were then heated for $10 \mathrm{~min}$ at $90^{\circ}$ while those for RNA synthesis were placed on ice. The contents of the tubes was then collected on glass fiber filters, washed thoroughly with $10 \%$ trichloroacetic acid and ethanol-ether $(1: 1, v / v)$ and dried. The precipitates were removed from the filters by heating in $1 \mathrm{ml}$ of $0.5 \mathrm{~N} \mathrm{NaOH}$ for $30 \mathrm{~min}$ at $90^{\circ}$. Aliquots of the $\mathrm{NaOH}$ digests were removed for liquid scintillation counting and protein determination. Results of these experiments are expressed as cpm incorporated $/ \mathrm{mg}$ of total protein. 
Preparation of muscle tRNA, soluble enzymes and polysomes. For the preparation of components for aminoacylation and cell-free protein synthesis, minced tibialis was homogenized in 2.5 vol. medium A [5] containing $0.25 \mathrm{M}$ sucrose, using a Polytron tissue homogenizer at a setting of $45 \mathrm{~V}$. tRNA and soluble enzymes were prepared from a portion of this homogenate as described previously [5]. tRNA and enzymes were prepared from rat liver and murine myeloma RPC-20 homogenates in a similar fashion [5]. E. coli acylating enzyme was prepared as described by Muench and Berg [6].

Polysomes were prepared from a supernatant fraction resulting from low speed centrifugation of the muscle homogenate [5]. The supernatant fraction was brought to $1.2 \%$ with Nonidet P-40 and allowed to stand in ice for $10 \mathrm{~min}$. Polysomes were collected by layering the detergent-treated supernatant fraction over $5-\mathrm{ml}$ cushions of medium A containing $1.1 \mathrm{M}$ sucrose and centrifuging for 2 to $2.5 \mathrm{hr}$ at $203,000 \mathrm{~g}$. Polysome pellets were resuspended in medium A containing $0.25 \mathrm{M}$ sucrose and generally used immediately for protein synthesis.

Conditions for cell-free aminoacylation, translation and transcription. Aminoacylation of tRNA was carried out in $100-\mu 1$ reaction mixtures containing: Tris- $\mathrm{HCl}, \mathrm{pH} 7.6,50 \mathrm{mM} ; \mathrm{MgCl}_{2}, 10 \mathrm{mM}$; ATP, $2.5 \mathrm{mM} ; 2$-mercaptoethanol, $5 \mathrm{mM}:\left[{ }^{3} \mathrm{H}\right]-$ or ${ }^{35} \mathrm{~S}$ ]amino acid, $50 \mu \mathrm{Ci} / \mathrm{ml}$; muscle tRNA, 0.35 to 6 $\mathrm{A}_{260} / \mathrm{ml}$, or rat liver tRNA, 6.2 to $15.6 \mathrm{~A}_{260} / \mathrm{ml}$; or myeloma RPC-20 tRNA, 3.2 to $16 \mathrm{~A}_{260} / \mathrm{ml}$ or E. coli tRNA, $8 \mathrm{~A}_{26 \mathrm{t}} / \mathrm{ml}$ and acylating enzyme, 1.2 to 4.3 $\mathrm{mg} / \mathrm{ml}$. Reaction mixtures were incubated for $10 \mathrm{~min}$ at $37^{\circ}$ and analyzed as described previously [5]. Results are expressed as cpm amino acid acylated/ $\mathrm{A}_{260}$ unit of added tRNA. Large scale $(2 \mathrm{ml})$ reaction mixtures were constructed to prepare $\left[{ }^{35} \mathrm{~S}\right]$ methionyl-tRNA from muscle and the acylated tRNA was isolated as described previously [7].

Reaction mixtures $(100 \mu)$ for protein synthesis contained: Tris- $\mathrm{HCl}, \mathrm{pH} 7.6,50 \mathrm{mM} ; \mathrm{MgCl}_{2}, 10$ $\mathrm{mM} ; \mathrm{KCl}, 80 \mathrm{mM} ; 2$-mercaptoethanol, $5 \mathrm{mM} ;$ ATP, $5 \mathrm{mM}$; GTP, $0.5 \mathrm{mM}$; phosphocreatine, $10 \mathrm{mM}$; creatine phosphokinase, $0.2 \mathrm{mg} / \mathrm{ml}$; nineteen nonradioactive amino acids, $0.1 \mathrm{mM}$ each; $\left[{ }^{3} \mathrm{H}\right]$ leucine, $50 \mu \mathrm{Ci} / \mathrm{ml}$; soluble enzymes, $0.6 \mathrm{mg} / \mathrm{ml}$ and polysomes, 0.24 to $1.2 \mathrm{~A}_{260} / \mathrm{ml}$. In some experiments, $\left[{ }^{35} \mathrm{~S}\right]$ methionyl-tRNA was present rather than $\left[{ }^{3} \mathrm{H}\right]-$ leucine, and $\left[{ }^{12} \mathrm{C}\right]$ leucine was added to those reaction mixtures to give a final concentration of $0.1 \mathrm{mM}$. Reaction mixtures were incubated for $20 \mathrm{~min}$ at $37^{\circ}$ and were analyzed as described previously $[5,7]$. Results are expressed as cpm amino acid incorporated/ $\mathrm{A}_{260}$ unit of polysomes added.

Reaction mixtures for RNA synthesis $(100 \mu \mathrm{l})$ were as described previously [8] except that all four nucleoside triphosphates were present at $0.1 \mathrm{mM}$ final concentrations. Wheat germ RNA polymerase II [9] was the enzyme source, calf thymus DNA was the template and $\left.{ }^{3} \mathrm{H}\right]$ UTP was the labeled triphosphate. Results are expressed as nmoles $\left[{ }^{3} \mathrm{H}\right]$ UMP incorporated $/ 100-\mu 1$ reaction mixture.

Protein was determined by the method of Lowry et al. [10] or by the method of Warburg and Christian [11].

\section{RESULTS}

Effects of Marcaine on RNA synthesis. Marcaine (0.01 to $0.50 \%$ final concn) was added to reaction mixtures (prepared as described above) containing pieces of rat tibialis anterior. Although good incorporation of $\left[{ }^{3} \mathrm{H}\right]$ uridine into RNA was observed, no effect of Mareaine on this incorporation could be detected (data not shown). The results presented below for protein synthesis indicate that Marcaine can penetrate muscle fibers; however, it seemed possible that the failure to observe any effect of Marcaine on transcription in muscle chunks might be due to its inability to penetrate the nuclear membrane of the muscle cells. To eliminate this possibility, the effect of the drug on transcription under cell-free conditions was examined. No attempt was made in this study to isolate muscle RNA polymerase; however, the polymerase used, from wheat germ, has been shown to be similar in properties to other eukaryotic RNA polymerases $[9,12]$. The data of Table 1 confirm the results described above in demonstrating that Marcaine has no effect on cellfree transcription at concentrations as high as $0.50 \%$ $(0.015 \mathrm{M})$. A slight inhibition of RNA synthesis by $1.0 \%$ Marcaine was observed in the experiments of Table 1, but this effect was not consistently observed in other cell-free transcription studies. Thus, both in vivo and in vitro studies suggest that Marcaine has no effect on RNA synthesis. It should be noted that, in all the studies described herein. appropriate controls were performed to eliminate any possible artifacts resulting from the effects of ethanol on RNA and protein synthesis.

Effects of Marcaine on protein synthesis. Figure 1 depicts the effects of Marcaine on $\left[{ }^{3} \mathrm{H}\right]$ leucine incorporation into protein by muscle chunks. As can be seen, inhibition of leucine incorporation is observed at Marcaine concentrations as low as $0.01 \%$ and incorporation is completely abolished at $0.50 \%$ Marcaine. The data presented in the preceding section eliminate the possibility that Marcaine

Table 1. Effects of Marcaine on transcription of calf thymus DNA by wheat germ RNA polymerase II*

\begin{tabular}{cc}
$\begin{array}{c}\text { Marcaine concn } \\
(\%, w / v)\end{array}$ & $\begin{array}{c}{\left[{ }^{3} \mathrm{H}\right] \text { UMP }} \\
\text { incorporated into RNa } \\
\text { (nmoles) }\end{array}$ \\
\hline 0 & 0.25 \\
0.05 & 0.27 \\
0.10 & 0.30 \\
0.15 & 0.29 \\
0.25 & 0.27 \\
0.30 & 0.29 \\
0.50 & 0.26 \\
1.00 & 0.21 \\
\hline
\end{tabular}

* Incubation and assay conditions were as described in Materials and Methods and in Ref. 8. One nmole $\left[{ }^{3} \mathrm{H}\right] \mathrm{UMP}$ incorporated is equivalent to $222,320 \mathrm{cpm}$. All experimental values were corrected by subtracting a zero time control. Wheat germ RNA polymerase II [9] was present at a concentration of 3.2 $\mathrm{mg} / \mathrm{ml}$. 


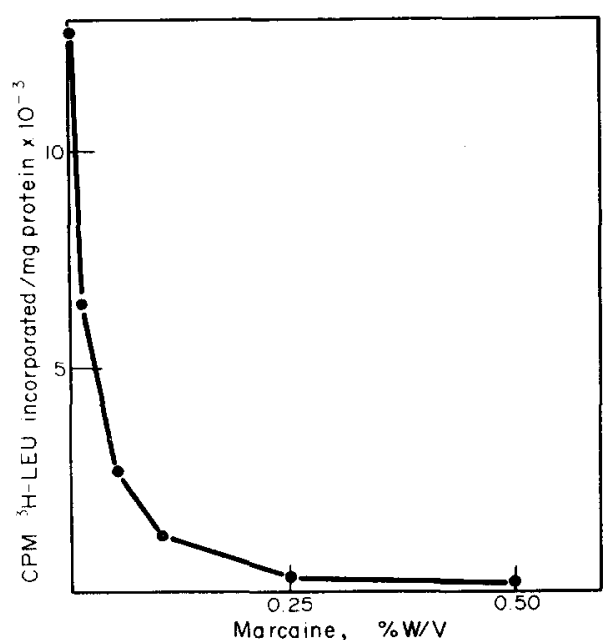

Fig. 1. Effects of Marcaine on protein synthesis by rat skeletal muscle pieces. Incubation and assay conditions were as described in Materials and Methods. Zero time controls were subtracted from experimental data. These and all other incorporation assays were performed in duplicate.

inhibits translation by first inhibiting transcription, but the possibility remained that the results obtained in the experiments of Fig. 1 were due to the effects of the drug on some other essential process, such as oxidative phosphorylation. To eliminate this possibility, cell-free components for protein synthesis were prepared and the effects of the drug on cell-free translation were studied. Figure 2 shows that Marcaine still inhibited $\left[{ }^{3} \mathrm{H}\right]$ leucine incorporation in a cell-free system. Inhibition of 11 per cent was observed at $0.10 \%$ Marcaine while the level of inhibition was 70 per cent at $0.50 \%$ Marcaine.

The process of protein biosynthesis is a complex one, and many individual biochemical events contribute to the synthesis of one peptide bond. It was of interest, therefore, to determine whether Marcaine inhibited protein synthesis generally, in a nonspecific fashion, or whether some specific partial

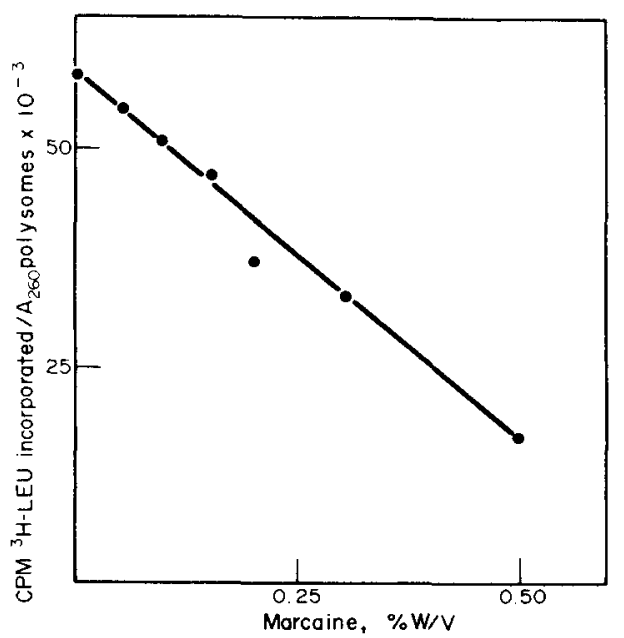

Fig. 2. Effects of Marcaine on cell-free protein synthesis using components from rat skeletal muscle. Conditions for cell-free protein synthesis were described in Materials and Methods. Data were treated as in the legend to Fig. 1. reaction of protein synthesis was the major target for the action of Marcaine. In the present study, the effects of the drug on activation and elongation reactions have been examined. Table 2 shows the effects of the drug on the esterification of muscle tRNA with leucine. It is evident that Marcaine did inhibit the acylation reaction in a concentrationdependent fashion (Table 2). The inhibition could not be overcome by increasing the amount of tRNA in the reaction mixture (data not shown), but inhibition was relieved by doubling the amount of enzyme used (Table 2).

In view of the results just described, it was of interest to examine the effects of Marcaine on the aminoacylation reaction more thoroughly. To this end, tRNA and acylating enzymes from rat liver, mouse myeloma RPC-20 and E. coli were prepared. Acylation of muscle, liver, myeloma and bacterial tRNA with the amino acids leucine, methionine, lysine and valine was performed in the presence and absence of Marcaine. The results of these experiments, shown in Table 3, allow several conclusions to be drawn. First, $0.5 \%$ Marcaine strongly inhibited acylation of tRNA with leucine in all three eukaryotic cell-free systems tested. Acylation with the other three amino acids was inhibited less severely than acylation with leucine. Second, although the degree of inhibition varied depending on which of the four amino acids was being used, $0.5 \%$ Marcaine was more effective in inhibiting acylation of muscle tRNA than tRNA from rat liver, and was more inhibitory to the acylation of liver tRNA than tRNA from the mouse myeloma. These results suggest that Marcaine may have some specificity for the charging system from skeletal muscle. Third, $0.5 \%$ Marcaine was completely ineffective in inhibiting acylation of tRNA from $E$. coli.

In order to examine the effects of the drug on polypeptide chain elongation, it was necessary to utilize conditions for cell-free protein synthesis in which possible inhibition of the activation and initiation reactions could be minimized. Effects of Marcaine on the activation reaction were avoided by performing the protein synthesis reactions with preacylated tRNA. tRNA acylated with high specific activity $\left[{ }^{35} \mathrm{~S}\right]$ methionine was prepared as described in Materials and Methods and in Ref. 7. The $\left[{ }^{35}\right.$ S $]$ methionyl-tRNA was then utilized in a cell-free reaction system, prepared as described in Materials

Table 2. Effects of Marcaine on aminoacylation of muscle tRNA with [ $\left[{ }^{3} \mathrm{H}\right]$ leucine*

\begin{tabular}{ccc}
$\begin{array}{c}\text { Marcaine concn } \\
(\%, \mathrm{w} / \mathrm{v})\end{array}$ & $\begin{array}{c}\text { Enzyme concn } \\
(\mathrm{mg} / \mathrm{ml})\end{array}$ & $\begin{array}{c}{\left[{ }^{3} \mathrm{H}\right] \text { leucine }} \\
\mathrm{A}_{\mathbf{2 6 0}} \text { tRNA } \\
(\mathrm{cpm})\end{array}$ \\
\hline 0 & 1.2 & 51,400 \\
0.10 & 1.2 & $25,100(49)$ \\
0.60 & 1.2 & $2,940(94)$ \\
0.0 & 2.4 & 142,940 \\
0.50 & 2.4 & $56,740(60)$ \\
\hline
\end{tabular}

* Aminoacylation conditions were as described in Materials and Methods. Experimental values were corrected by subtracting zero time controls, and figures in parentheses represent per cent inhibition by Marcaine. 
Table 3. Effects of Marcaine on the acylation of $t$ RNA with various amino acids*

\begin{tabular}{|c|c|c|c|c|}
\hline \multirow{2}{*}{$\begin{array}{l}\text { Acylating } \\
\text { system }\end{array}$} & \multicolumn{4}{|c|}{$\begin{array}{c}\text { Amino acid acylated/A } A_{26 i} \text { tRNA } \\
(\mathrm{cpm})\end{array}$} \\
\hline & Leucine & Methionine & Lysine & Valine \\
\hline Rat muscle & 172,000 & 49.600 & 48.900 & 4.600 \\
\hline Rat muscle + Marcaine & $300(90)$ & $25.500(45)$ & $8.600(82)$ & $2,000(57)$ \\
\hline Rat liver & 98.700 & 16,900 & 233.900 & 20,500 \\
\hline Rat liver + Marcaine & $7,800(92)$ & $11,200(34)$ & $114,800(51)$ & $13.900(32)$ \\
\hline Mouse myeloma & 635,500 & 39,800 & 536,400 & 44.700 \\
\hline Mouse myeloma + Marcaine & $111,300(82)$ & $36,900(7)$ & $427.500(20)$ & $31.500(30)$ \\
\hline E. coli & 484.700 & 171,000 & 353,600 & 28.800 \\
\hline E. coli + Marcaine & $567,900(0)$ & $185,000(0)$ & $453,600(0)$ & $33,800(0)$ \\
\hline
\end{tabular}

* Acylation of tRNA was performed as described in Materials and Methods. All reaction mixtures contained about $3 \mathrm{mg} / \mathrm{ml}$ of acylating enzyme. Data in the table have been treated as described in the legend to Table 2 and numbers in parentheses represent per cent inhibition by Marcaine.

Table 4. Effects of Marcaine on polypeptide chain elongation in vitro*

\begin{tabular}{ccc} 
Expt. & $\begin{array}{c}\text { Marcaine concn } \\
(\%, w / v)\end{array}$ & $\begin{array}{c}{\left[{ }^{\mathrm{m}} \text { S]methionine }\right.} \\
\text { incorporated } / \mathrm{A}_{2611} \\
\text { polysomes } \\
(\mathrm{cpm})\end{array}$ \\
\hline I & 0 & 3190 \\
II & 0.50 & $2800(12)$ \\
& 0 & 3050 \\
& 0.50 & $2040(33)$ \\
\hline
\end{tabular}

* Procedures for preparation of [i5 $S$ ]methionyl-tRNA and for cell-free protein synthesis were as described in Materials and Methods. Incubation mixtures contain $10^{6} \mathrm{cpm} / \mathrm{ml}$ of $\left[{ }^{35} \mathrm{~S}\right]$ methionyl-tRNA. Data were treated as described in the legend to Table 2.

and Methods, but containing $\left[{ }^{12} \mathrm{C}\right]$ methionine to prevent reacylation of the muscle $t R N A$ during protein synthesis. To eliminate possible effects of Marcaine on the initiation reactions, cell-free incubations were performed at $10 \mathrm{mM} \mathrm{Mg}^{2+}$ and at $37^{\circ}$. Both these values are well above the optima for physiological initiation of protein synthesis in eukaryotic systems $[13,14]$. Results of experiments using [ ${ }^{35} \mathrm{~S}$ ]methionyl-tRNA as the source of labeled amino acid are reported in Table 4 . It is obvious that the levels of amino acid incorporation are lower in Table 4 than in Fig. 2 even though the methionine used has a higher specific activity than the leucine. This difference results from the fact that much less total amino acid was added to the reaction mixtures as $\left[{ }^{35} \mathrm{~S}\right]$ methionyl-tRNA than was added as $\left[{ }^{3} \mathrm{H}\right]$ leucine. Significant $\left[{ }^{35} \mathrm{~S}\right]$ methionine incorporation was observed nevertheless in the experiments of Table 4, and it can be seen that, in two separate experiments, Marcaine at 0.50 per cent inhibited this incorporation by about 23 per cent on the average.

\section{DISCUSSION}

The results presented above demonstrate directly that Marcaine, while without effect on RNA synthesis, does inhibit protein synthesis in muscle. At a concentration of $0.50 \%(0.015 \mathrm{M})$, the drug inhibited overall amino acid incorporation, activation and elongation in a cell-free system. The maximum concentration of Marcaine used in most of these studies $(0.50 \%)$ was chosen to correspond to the concentration of commercially available Marcaine used in skeletal muscle transplantation studies. However, the data of Figs. 1 and 2 and Table 2 indicate that lower concentrations of Marcaine are effective in inhibiting overall protein synthesis and aminoacylation.

It will be noted in comparing the data of Figs. I and 2 above that $0.50 \%$ Marcaine produced a greater degree of inhibition of protein synthesis in muscle chunks than in a cell-free system derived from the same muscle. The reason for this discrepancy is not clear, but it seems possible, if not likely, that the drug affects other biochemical pathways (oxidative phosphorylation, for example) whose activities may be essential for continued protein synthesis in intact muscle. Because of this possibility, an investigation of the effects of the drug on mitochondrial function and on the enzymatic pathways involved in nucleo side triphosphate biosynthesis and inter-conversion would be illuminating.

The data of Tables 3 and 4 indicate that Marcaine affects both the activation and elongation reactions of protein synthesis and that the degree of inhibition of aminoacylation was higher than for elongation under the assay conditions employed. In addition. the data of Table 2 suggest a direct effect of the drug on the aminoacyl-tRNA synthetase since an increase in the concentration of enzyme in the reaction mixture led to decreased inhibition of aminoacylation by Marcaine. An increase in tRNA concentration was without effect.

The fact that Marcaine was a less effective inhibitor of aminoacylation of tRN A from rat liver and mouse myeloma than tRNA from muscle suggests that the drug possesses some specificity for the acylation apparatus from skeletal muscle. Kinetic studies on the inhibition of $\left[{ }^{3} \mathrm{H}\right]$ leucine acylation are in progress to verify this hypothesis. Perhaps the most interesting observation regarding the effect of Marcaine on aminoacylation was its complete inability to inhibit the acylation of $E$. coli tRNA with 
the four amino acids tested. Indeed, Marcaine stimulated the acylation of $E$. coli $t R N A$ with all four amino acids (Table 3). The mechanism of this stimulation is unknown at this time. The studies presented here should be extended to other prokaryotes and other amino acids should also be tested, but the data of Table 3 suggest that Marcaine may belong to the group of translational inhibitors specific for the protein synthetic apparatus of eukaryotes.

We have not yet examined the effects of the drug on the initiation reactions of protein synthesis, but none of the cell-free studies described was performed under conditions favoring physiological initiation. It seems likely, therefore, that the results of Tables 2-4 are sufficient to explain the inhibition of overall amino acid incorporation observed in Fig. 2. In conclusion, it seems quite likely that the inhibitory effects of Marcaine on protein synthesis make a significant contribution to the observed degeneration of Marcaine-treated skeletal muscle after transplantation.

Acknowledgements-This research was supported by grants from the University of Michigan Institute of Science and Technology. from the Michigan Memorial Phoenix Project, and, in part, by grant 5R01-CA12752-06 from the National Cancer Institute.

\section{REFERENCES}

1. L. TeLuvio, Annls Chir. Gynaec. Fenn. 52, 513(1963)

2. E. C. B. Hall-Craggs, Exp Neurol. 43, 349 (1974).

3. K. R. Wagner, S. R. Max, E. M. Grollman and C. L. Koski, Expl Neurol. 52, 40 (1976).

4. S. R. Max and D. H. Rifenberick, Neurochemistry 24, 771 (1975).

5. K. R. Bridges and G. H. Jones, Biochemistry 12, 1208 (1973).

6. K. Muench and P. Berg, in Procedures in Nucleic Acid Research (Eds. G. L. Cantoni and D. R. Davies), pp. 375-83. Harper and Row, New York (1966)

7. G. H. Jones, Biochemistry 13, 855 (1974).

8. G. H. Jones, Biochemistry 15, 3331 (1976).

9. J. J. Jendrisak and R. R. Burgess. Biochemistry 14, 4639 (1975).

10. O. H. Lowry, N. J. Rosebrough, A. L. Farr and R. J. Randall, J. biol. Chem. 193, 265 (1951).

11. O. Warburg and W. Christian, Biochem. Z. 310, 384 (1941).

12. J. J. Jendrisak and W. M. Becker, Biochem. J. 139, 771 (1974)

13. M. Jacobs-Lorena and C. Baglioni, Biochemistry 11, 4970 (1972).

14. T. Zehavi-Willner and S. Pestka, Archs Biochem. Biophys. 172, 706 (1976). 